\section{Behind the Rhetoric}

The Institutional Basis of Social Exclusion and

\section{Poverty}

\section{Martin Evans}

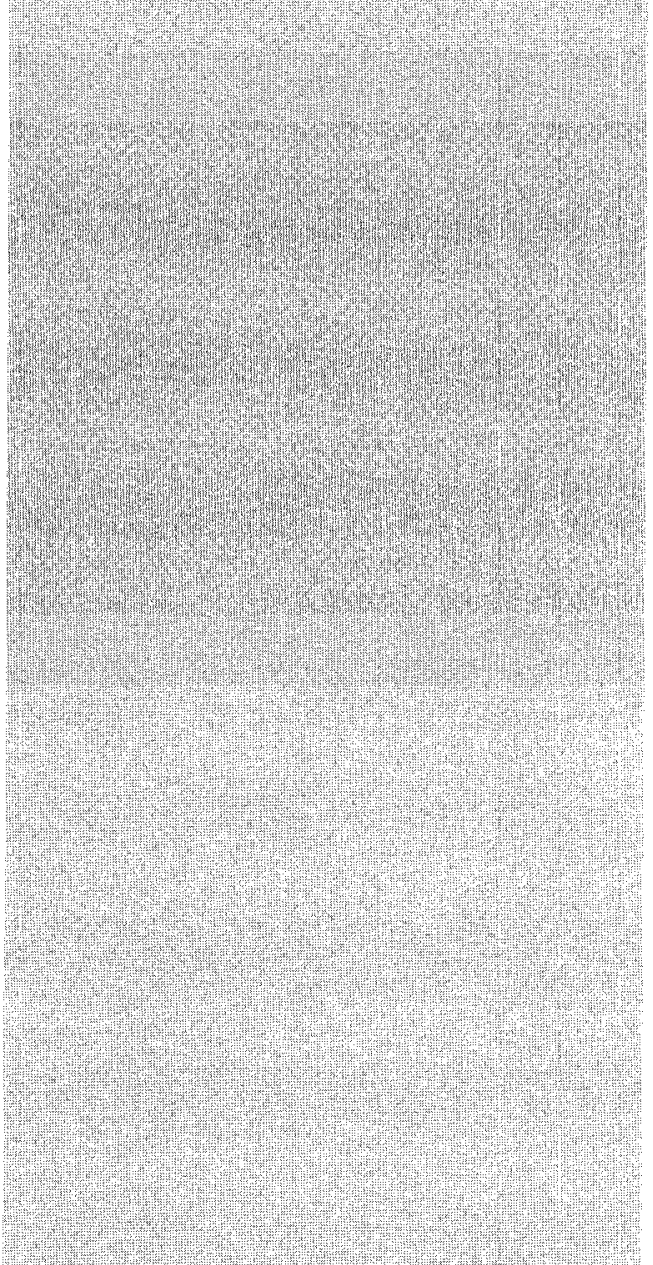

IDS Bulletin Vol 29 No 11998

\section{Introduction}

Social policies designed to help the poor rest on basic assumptions and values about deprivation and an appropriate response. By comparing these assumptions internationally we can learn much about the aims of policy, its design, and its performance. I argue that theoretical discussion of policy assumptions, for instance on the paradigmatic differences between social exclusion and poverty, as discussed by Silver (1994), Silver and Wilkinson (1995) and de Haan (1997), should always be strongly grounded in their policy context. First, I argue that social exclusion has arisen in the European discussion at a time when the performance of welfare systems has been criticised strongly for failing to prevent poverty and hindering economic development. Second, I compare the policy contexts of French 'social exclusion' and British 'poverty' concepts using social assistance as a template. Last, I return to the criticisms of welfare state performance and economic development and highlight the need to maintain a social and institutional context beyond that of western industrialised countries and their welfare institutions.

\section{Social Exclusion}

European Union social policy has moved away from the concept of poverty towards social exclusion since the early 1990s. It is no coincidence that this coincided with a worsening economic climate, higher social and demographic profiles of 'need' and high fiscal pressure on welfare provision. The French were the main instigators of the new approach. This had developed since the mid1970s, as a response to the failure of their existing solidaristic social security and welfare programmes to meet the new arising needs. My first point is that the discovery of these failings and gaps is an important part of the development of the concept of social exclusion. In other countries, poverty research, primarily on income poverty, has had a longer history of the measurement of such failings and gaps - for example in Townsend's work in Britain (1979).

Social exclusion is multidimensional and dynamic in character. A clear exposition of this is by Commins (1993), who presents four dimensions, i.e. exclusion from: 
1 civic integration - a failure of democratic and legal systems;

2 the labour market;

3 welfare state provision;

4 family and community.

Of these, 2, 3 and 4 seem to be mostly responsible for poverty. ${ }^{1}$ But such concerns are not the sole prerogative of those who wish to reduce social exclusion; anti-welfare commentators argue that social policy itself causes or exacerbates such 'breaking of social bonds' (Murray 1984). Thus, there is a danger in accepting 'social exclusion' as a wide definition of potential disadvantage and deprivation. To avoid this, we need to be analytically rigorous. Social inclusion has to be more than merely a rhetorical aim of very differently conceived and motivated policies, particularly in an international context.

One reason for confusion is that 'poverty' and 'exclusion' are the outcome of institutional processes, social and economic. Indeed, the 'poor' and 'excluded' define themselves and are defined by such institutions and processes. Yet institutions vary markedly from place to place and from time to time. To illustrate this I outline French and British institutions which provide a minimum income guarantee.

\section{Social Assistance in France and Britain}

Silver (1994) outlines the different traditions of philosophical and sociological thought in Britain and France, and these are fundamental to a historical understanding of the two traditions. However, it is also essential to understand the very different social and economic development profiles. The British concern for poverty changed during nineteenth century industrialisation to reflect the emergence of the urban poor. This urban poverty became the concern for contemporary novelists, philanthropists and social scientists (Himmelfarb 1984, 1991). The Poor Law was amended to deter claims upon it that arose from increased involvement in the labour market. Emphasis moved to institutional help, to ensure that assistance was always worse than wages or the kindness of kith and kin.

France industrialised later than Britain and poverty was mostly a rural problem in the nineteenth century. The Comité de Mendicité had tried to organise a vast programme of public assistance to the poor at the end of the eighteenth century, but failed. Local authorities took responsibility for poverty without the cruel system of workhouses.

Increasing pauperism was thus of concern to both countries (Merrien 1994), but there was a very different emphasis on the problem of voluntary poverty. This was based on both the different economic experience and on different ideological preferences - economic liberalism was stronger in Britain. Further, dominant religious traditions complemented and reinforced such different approaches: the Protestant ethic promotes individual professional success, while the Catholic doctrine is founded on the moral value of charity and thereby supports a relation of exchange between the rich and the poor.

In Britain, 'poverty' became the concern of surveys of the urban poor by Rowntree and Booth. In the early twentieth century urban local authorities challenged the assumptions of the old Poor Law, and the Fabian and Liberal social policy gravitated towards the concept of a 'national minimum'. It was in this tradition that the post-war British institutions for social security were set up.

Next I discuss the different contexts of social assistance in France and Britain. I use the term social assistance to mean state 'safety net' income transfers designed to help the poorest, subject to a test of resources. They are a third pillar of state transfers, alongside social insurance and non-contributory categorical payments such as family allowances, ${ }^{2}$ and British disability benefits. Social assistance is dominated by the national context in every country. For the sake of argument, this can be analysed along two dimensions:

- the fiscal context of taxes and transfers: the way

\footnotetext{
'I use Ringen's (1988) term to define poverty broadly, as a potential measure of income (indirect) or living standards (direct).
}

\footnotetext{
'While some French family allowances are income tested they are universal in approach and are not aimed at the poorest.
} 
each national assistance scheme meets the 'gaps' in income provision from employment, family, investment and savings and social security.

- the institutional context: each assistance scheme also relates to provision of non-cash services such as care, health services, housing, and social work, by the state as well as NGOs and the family.

\section{The Fiscal Context}

The fiscal context of social assistance in France and Britain underpins much of the difference in concepts of poverty and social assistance. Both countries saw social insurance as the linchpin for economic security against unemployment, sickness and old age. However, Beveridge based the British system on a model of flat rate benefits designed to maintain a subsistence minimum. Britain introduced a comprehensive national assistance scheme based on rates at or near social insurance benefit rates, and nationalised the health service, transport and a wide range of core industries.

France adopted and expanded the earnings-related insurance principle that sought to maintain living standards rather than protect a minimum standard of living. The only national forms of social assistance were means-tested top-up pensions for the sick and elderly that could be claimed as part of the pension or sickness benefit system (Minimum Vieillesse and Minimum Incapacité). Otherwise the local authorities operated social assistance alongside social work and care services.

The French concern for social exclusion springs from the break-down of this system. Social insurance had always been part of a wider package of social policy designed to maintain social solidarity. The Republican ideology sees social cohesion as fundamental to social and economic well-being. Hence, when in the mid-1970s Lenoir pointed to groups who were excluded from the Republican social contract he termed them les exclus (1989). The response was to widen the scope of social assistance to the disabled, the lone parents, and later to the unemployed without social insurance cover. This first widening of coverage of social assistance was to combat social exclusion arising from uninsurable contingencies such as lone parenthood and non-industrial disability.
In the 1980s, demands from unemployment came to place great pressures on the system of social assistance. There was a move towards extending a minimum guaranteed income to all, which gave rise in 1989 to the introduction of a non-categorical Revenu Minimum d'Insertion (RMI). This, alongside (rather than underneath as a lower 'safety net') provided assistance for all those who did not fit the categories covered by previous schemes or who otherwise failed to meet their rules of entitlement This was a major instrument to combat 'social exclusion'.

In Britain, few were 'excluded' (in the French sense) because coverage by the assistance safety net was comprehensive, although failure to take up assistance benefits and other means-tested schemes undermined this comprehensiveness. However faced with similar concerns in the 1970s, Britain moved towards providing universal benefits (in particular for the disabled) which would lift people who nevertheless were claimants or potential claimants of assistance - out of 'poverty'. Thus, social assistance grew in coverage as social insurance was deliberately rolled back, in particular for the unemployed. Demands from lone-parenthood and non-insured sickness and disability grew (Evans 1998). But the aims of social assistance changed in the face of increasing demands. Its comprehensiveness was weakened by several changes to entitlement and coverage. Indeed, the use of social assistance income as a measure of poverty was abandoned, and recipients were no longer officially recognised as 'poor'.

Drawing these very brief overviews together, there is conflicting evidence for convergence and divergence in the fiscal context of social assistance. France has moved towards a universal safety net similar to the British model. Britain has created more 'gaps' in coverage and is thus moving towards the French approach prior to RMI. In this respect, there is a need for an empirical appraisal of the effectiveness of French and British assistance in responding to poverty and social exclusion, which can cut through the different and changing national policy rhetoric.

But equally, there is evidence of divergence. In France only 10 per cent of the people rely on assistance, as compared with 20 per cent in Britain 
(Evans et al. 1995). Social assistance has less work to do because of the range of other provision in the French fiscal context. Therefore, there is more scope to do it differently than in Britain, where cash benefit delivery and strict monitoring of the conditions of entitlement are really the only practical policy aims. French concerns can be more general, and can involve a wider range of aims about insertion than the British concern about labour market incentives and 'welfare to work'. This insight leads us to the wider issue of the institutional context in which exclusion and poverty are combated.

\section{The Institutional Context}

Paradoxically, one of the main reasons why French policies to combat social exclusion have a wider concern than cash transfer delivery is because there is a need for greater intervention for the poor in other areas such as health and housing. This was recognised by Vanlerenberghe in his report on RMI (1992). French Securité Sociale includes health care, and hence those without specific rights through employment and contribution histories are, in general, excluded. The British National Health Service provides a universal right to health care for all and avoids this problem. Similarly, homelessness in Britain gives rise to some statutory duties, and social housing is directed at the poor. In France, the pro-poor emphasis is not so strong, and 'exclusion' in terms of access to services is, in general, a greater risk.

Turning to active employment policies and welfareto-work programmes, social insurance covers the majority of French unemployed, whereas in Britain the vast majority is on means-tested assistance. The priority given to ensuring incentives to work is thus institutionally different as well as stemming from a different ideological and conceptual framework about poverty and social exclusion. ${ }^{3}$ Compared to the treatment of unemployed social assistance claimants in Britain, insertion for RMIstes is far wider than mere labour market behaviour and includes re-insertion into social and familial networks. RMI was designed to pick up those who fell out of the jurisdiction of main institutions of French social welfare, and hence social work was part of its logic. However, many RMIstes do not, in fact, have contrats d'insertion (a statement of obligations that accompanies entitlement to benefit), and French social workers are reluctant to act as benefit policemen and surrogate employment exchanges.

Thus social exclusion in the institutional sense, in France, identifies people who have poor relationships with the main welfare agents. These are both the state, through its solidaristic social insurance, and the family, which in theory has a greater responsibility to care for and maintain its adult kin members through the code civile. It also means access to employment because having a job involves mutual obligations between employees and employers and is the fundamental route to securité social. However, other French institutions are also designed to hold a Republican ideal of cohesive solidarity under the umbrella of the constitution. Thus exclusion and insertion can be used in a particular context - say for unemployment where exclusion refers to the uninsured unemployed and insertion is a range of active and passive labour market policy - or to a much wider and less defined social malaise.

\section{Policy Rhetoric and Response}

Paugam, reviewing a wide range of research states:

il ne peut exister de définitions absolues d'exclusion. Cette notion est relative, variable selon les époques et les lieux. Il est déraisonannable de prétendre trouver une définition juste, objective - et distincte du débats social - sans tomber dans le piège de la catégorisation de populations spécifiques dont on sait que les frontières qui les distinguent des autres groupes sociaux sont jamais claires (Paugam 1996: 565).

Paugam is right, but I suggest that it is wrong to extrapolate from a breadth of potential definitions of social exclusion to a position where it can mean anything to anyone. 'Social exclusion' must include a definition of at least the group and the reason for or the process of its exclusion. In the wider sense, it must refer to a group of people with different profiles of exclusion which must be made explicit. Otherwise the term is unspecific - like the term 'road user', which could mean a cyclist, a taxi-driver

${ }^{3}$ For a full discussion of unemployment and poverty traps and incentives in the two systems, see Evans (1996). 
and a Juggernaut, all with different and conflicting profiles and needs.

The attraction of the unspecified wide definition is that is overtly rhetorical. This is very easy to demonstrate from the French debate. All political parties, from the socialists to the Front National, are against exclusion, but from very different viewpoints. They all agree on a cohesive national ideal, but have very different notions of how to make that Republican ideal work. Indeed, at the time that the June 1997 elections were called, the French Parliament was debating new laws to combat social exclusion, and these contained elements which were directly comparable in part to British concerns about welfare-to-work. New employment contracts for the unemployed were proposed, breaking with the classic French model of employment protection and minimum wages in order to help insertion into the labour market.

Any conceptual discussion of social exclusion, including its difference from poverty, should avoid incorporating this rhetoric uncritically. This is not to say that the concept of poverty is not used rhetorically, far from it. The New Labour government in Britain has promised to reduce poverty and inequality and to tackle social exclusion. But there are questions about where this rhetoric is leading. Can New Labour reconcile concerns for reducing poverty and inequality - and the specific aim to tackle the social pathology of the poor - with the resources required to do so? Much has been promised to help the unemployed into work (see also the discussion by Robinson in this volume), and to extend this help to lone parents and the long-term sick. But how will poverty and inequality be altered for those for whom employment is not appropriate? The poorest pensioners, the severely disabled, and others who cannot work have been promised a fall in the relative levels of their social security benefits in comparison to those who are working. While 'welfare-to-work' may reduce poverty headcounts, poverty gaps and inequality may well increase. This combination of policies could actually increase social exclusion, as groups of benefit claimants fall further below the life style of the remainder of society.

It is also unclear how New Labour view 'social exclusion'. Some see growing inequality in the distribution of rights and resources as an increase in social exclusion, but the dominant theme seems to be an alternative American-style view. Social exclusion is seen as a problem of an underclass and a behavioural and moral issue. It seems Labour hopes to solve the recidivism of the underclass by 'compassion with a tough edge'.

At the heart of this is a dilemma about the nature of social exclusion and its relationship with income poverty and inequality. Social exclusion is seen as multi-dimensional only for the underclass where deprivation is seen as dysfunctional and a threat to wider social order. The proposed response is informed by a moral agenda and its injunction to judge, blame and solve the problem by forcing changes in individual behaviour. Little regard has been given to the multi-dimensional nature of a wider view of social exclusion because all attention has been focused on the solving of 'poverty' through attachment to the labour market.

Labour's solution to what they think is wrong in British policies (after 17 years of Conservative governments) are programmes which largely accept the Conservative individualistic approach. A huge one-off programme of welfare-to-work policies essentially just more of the same - is supposed to solve the supply problems of the labour market. A neo-classical view of the undeserving poor will impose a regime of 'tough love'. The institutional and policy contexts are preserved. For instance, those whose rights to the British comprehensive safety net were weakened during the 1980s and 1990 s are not reenfranchised. Lone parents will continue to have their benefit entitlements cut. The weakest may become poorer and possibly socially excluded, but will not be accepted as the latter until their children steal cars, take drugs or are expelled from school. An alternative approach, of widening access to rights, investing in individual and community resources and fostering better relationships with informal, private and state service providers is hamstrung by the prohibitions on spending more, on more progressive income taxation and on meaningful institutional change in the government and delivery of welfare services. 


\section{Policy Analysis: The Problem of the Counterfactual}

An approach which studies the institutional basis of social exclusion as well as its characteristics at the individual level could contribute to a more reasoned appreciation of welfare state failings. Piachaud (1997) outlines two main fields of potential research. The first is a rigorous examination of the beneficial effects of welfare provision, together with its gaps and failings. This would help to assess more fully the success of welfare institutions and their response to poverty and social exclusion. The second is an analysis of the social and institutional basis of the economic counterfactual. This counterfactual can be a historical one (for instance what happened before social security in western industrial economies) and an international one which can learn from the modern experiences of informal welfare institutions in developing countries.

It is alleged that social assistance and social security create labour market inefficiencies. Put simply, it is argued that if social security and social assistance were removed, or were at lower rates, unemployment would be less extensive and of shorter duration. Thus, policies designed to counter social exclusion and poverty are alleged to fail because they create or worsen the problems they purport to help. A problem with this suggestion is that it criticises institutions but puts forward a counterfactual which has none of its own. The proposed alternative is one that exists in an untainted pure realm of individualised economic efficiency. If social behaviour or institutions are added, the argument is less convincing. Lower benefits may improve incentives to work but would also necessitate a search for an alternative source of subsistence. This may mean more time queuing at the soup kitchen for basic nourishment, begging, borrowing, and other activities, and hence less time looking for work. Nonmonetary means of subsistence may well have 'disincentive effects' themselves. Can subsistence farming be immediately abandoned for a job?

By the same token, social relationships may either help or hinder individual labour market behaviour. Family, neighbours or friends may help tend the subsistence crops to enable one to look for earned employment, but this could involve obligations to them that would subsequently be difficult to meet. The family and community are often posited as an alternative to social security, but here historical evidence is ignored. Laslett (1983) and others have exposed the myth of the British 'extended family' but it is still often alluded to. There is also a presumption that the poor had or could have increased levels of familial support that have been weakened by social security. Again, this ignores crucial historical evidence to the contrary. In nineteenth century Preston,

of all households whose family standard of living was within $4 s$ of the primary poverty line, only $2 \%$ contained kin none of whom had a recorded means of support; of those with a standard of living of 20 s and above, the figure was $11 \%$. By contrast, $9 \%$ of the first group and $12 \%$ of the second contained kin at least one of whom was self supporting (Anderson 1972: 231).

The granting of the first state pensions in 1905 is widely reported as enabling the elderly to stay in their children's homes because they could contribute to the household budget rather than be a drain (Gilbert 1966). Poor families are smaller, and large households are most often associated with wealth. The negative correlation of poverty with family and household size has been observed across a huge range of societies: for instance, Northern India (Shah 1973), Italy (Banfield 1958), and in aboriginal and hunter gathering societies (Sahlins 1972).

In short, there is no simple counterfactual for family structures before or without 'social security' and hence no simple counterfactual for how families would operate in its absence. Any generalisation about family structure and social change across time and between countries is dangerous (Harevan 1991). Where family ties remain strong then there is often a 'modern' economic reason - as well as 'traditional values' such as kin-based altruism. Thus, in rapidly growing countries such as Japan and Korea, the continued high proportion of three generational households is partly because elderly parents who live with their adult children are expected to participate in the economy of the household - in providing child care to allow greater labour market participation by women and/or contributing towards high costs of urban housing (Kumagai 1986; De Vos and Lee 1993; Morgan and Hirosima 
1983). Respect for parents and obligations to parents are both modern and traditional for these families. Seeing social exclusion and poverty in their institutional contexts may help to counter those who make rhetorical claims about the failure of welfare states.

\section{Conclusions}

If we take an institutional focus, the move by the European Union to concentrate on social exclusion rather than poverty provides opportunities and dangers. The dangers are that 16 countries may agree on using the term and on its conceptual basis but are free to interpret it differently because their social and economic institutions differ so widely. The opportunity comes from the fact that the institutional context is so central to the term social exclusion. This opportunity enables each profile of social exclusion to be analysed in terms of both the processes of exclusion and the responses to it. We amplify the dangers and underplay the opportunities if we remain too long discussing conceptual differences and their ideological and philosophical basis.

There are considerable methodological difficulties in international comparison. These have been extensively explored in comparisons of income poverty. For instance Atkinson et al. (1996) have shown the changes in ranking of French and British poverty when assumptions about income definitions, equivalence scales and poverty measures are altered. Comparing social exclusion has a wider agenda and hence requires both more appreciation of context and a wider range of methods.
These are not just methodological questions but open up the area of how policy can best be designed to respond. While giving state transfers may be appropriate in itself for short-term excluded, those faced with more substantial barriers, from ethnicity, language, poor skills, psychiatric illness etc., require more. Income poverty may be a repeated experience for some individuals as they move between reliance on benefits and short-term jobs and/or poorly paid work. Cross-sectional counting of the 'excluded' is likely to miss these people when they are in work. The French debate stresses that there are people on the margins of exclusion, and has introduced the term précarité. There is no equivalent concept in Britain, although recent researchers have found that there is a significant level of dipping in and out of welfare and work (Bryson and Marsh 1996; Jarvis and Jenkins 1996: Bryson, Ford and White 1997).

If poverty and social exclusion are linked to institutional provision, empirically measured, and the responses evaluated, then the debate can live in an interchange of applied research. For France and Britain, this has two distinct but complementary advantages. In Britain, we may have to be more conceptually brave and rigorous and realise how far the current institutional response governs the way we appreciate the problem. In France, greater emphasis on empirical policy evaluation may make the rhetorical debate more transparent. Such a research agenda could examine and evaluate the role of state transfers and other social policy of different kinds in preventing and alleviating poverty and in responding to and overcoming social exclusion. This would enable us to estimate more accurately how well such policies perform as well as the intellectual rigour of their conceptual basis.

\section{References}

Anderson, M., 1972, 'Household structure and the industrial revolution; mid-nineteenth-century Preston in comparative perspective', in P. Laslett and R. Wall, Household and Family in Past Time, Cambridge: Cambridge University Press

Atkinson, A et al., 1996, 'Comparing poverty in France and the United Kingdom', in S. Jenkins, A. Kapteyn and B. van Praag, (eds), The Distribution of Welfare and Household
Production, Cambridge: Cambridge University Press

Banfield, E., 1958, The Moral Basis of a Backward Society, New York: Free Press

Bryson, A. and Marsh, A., 1996, Leaving Family Credit, London: HMSO

Bryson, A., Ford, R. and White, M., 1997, Making Work Pay: Lone Mothers, Employment and Well-Being, York: York Publishing Services 
Commins, P. (ed.), 1993, Combating Exclusion in Ireland 1990-94: A Midway Report, Brussels: Observatory on National Policies to Combat Social Exclusion, Commission of European Countries

De Vos, S. and Lee, Y-J., 1993, 'Change in extended family living among elderly people in South Korea, 1970-1980', 1990, Economic Development and Economic Change Vol 42 No 2:377-93

Evans, M., 1998, 'Social security: dismantling the pyramids?', in Glennerster (ed.), The State of Welfare (2nd edition), Oxford: Oxford University Press, forthcoming

_ 1996, 'Families on the dole in Britain, France and Germany, Welfare State Programme Discussion Paper No 117, London: London School of Economics

Evans, M. et al., 1995, 'Chunnel vision: poverty, social exclusion and the debate on social welfare in Britain and France', Welfare State Programme Discussion Paper No 115, London: London School of Economics

Gilbert, B., 1966, The Evolution of National Insurance in Great Britain: The Origins of the Welfare State, London: Joseph

de Haan, A., 1997, 'Poverty and social exclusion: a comparison of debates on deprivation', Poverty Research Unit Working Paper No 2, Brighton: University of Sussex

Harevan, T., 1991, 'The history of the family and the complexity of social change', The American Historical Review Vol 96 No 1

Himmelfarb, G., 1984, The Idea of Poverty: England in the Early Industrial Age, London: Faber

_-, 1991, Poverty and Compassion: The Moral Imagination of the Late Victorians, New York: Knopf

Jarvis, S. and Jenkins, S., 1996, 'Changing places: income mobility and poverty dynamics in Britain', Working Paper of the ESRC Centre on Micro-Social Change No 96-19, Colchester: ESRC Centre on Micro-Social Change
Kumagai, F., 1986, 'Modernization and the family in Japan', Journal of Family History Vol 11 No 4: $371-82$

Laslett, P., 1983, The World We Have Lost Further Explored, London: Routledge

Lenoir, R., 1989, Les Exclus: Un Français sur Dix, (4th edition), Paris: Éditions de Seuil

Merrien, F.-X., 1994, 'Divergences franco-britanniques', in Merrien, F.-X. (ed), Face à la Pauvreté: L'Occident et les Pauvres, Hier et Aujourd'hui, Paris: Les Editions de l'Atelier

Morgan, S. and Hirosima, K., 1983, 'The persistence of extended family residence in Japan: anachronism or alternative strategy?' American Sociological Review Vol 48, April: 269-81,

Murray, C., 1984, Losing Ground, New York: Basic Books

Paugam, S. (ed.), 1996, L'Exclusion: l'État des Savoirs, Paris: Éditions la Découverte

Piachaud, D., 1997, 'Social security and the prevention of poverty: reconstructing the research agenda', mimeo, London: London School of Economics

Ringen, S., 1988, 'Direct and indirect measures of poverty', Journal of Social Policy Vol $17 \mathrm{Pt} 3$ : 351-365

Sahlins, M., 1972, Stone Age Economics, Chicago: Aldine-Atherton

Shah, A., 1973, The Household Dimension of the Family in India, Delhi: Orient Longman

Silver, H., 1994, 'Social exclusion and social solidarity: three paradigms, IILS Discussion Paper No 69, Geneva: IILS

Silver, H. and Wilkinson, F., 1995, 'Policies to combat social exclusion: a French-British comparison', IILS Discussion Paper No 83, Geneva: IILS

Townsend, P., 1979, Poverty in the United Kingdom: A Survey of Household Resources and Standards of Living, Harmondsworth: Penguin

Vanlerenberghe, P., 1992, RMI, le Paru de l'Insertion: Rapport de la Commission Nationale d'Évaluation du RMI, Paris: La Documentation française 